\title{
EFEKTIVITAS PERATURAN BUPATI BREBES NOMOR 026 TAHUN 2015 TENTANG PEMBERDAYAAN MASYARAKAT DALAM PENURUNAN ANGKA KEMATIAN IBU \\ DAN BAYI MELALUI MAKLUMAT DUKUN BAYI ${ }^{1}$
}

Dwihatna Mustikarini Nugroho, Sulistyandari, Siti Muflichah

\begin{abstract}
This study aims to know and analyze the effectiveness of the regulation of the Regent of Brebes No. 026 the year 2015 and to know and analyze the factors that impede the implementation of the regulations of the Regent of Brebes No. 026 the year 2015. This research includes juridical sociological research categories. The data obtained are presented in narrative form. Based on the research results and discussion conclusion to be drawn as follows: first, Bupati of Brebes Regulations. No. 026 the year 2015 About community empowerment In Decreasing maternal mortality and infant mortality Through Baby Shaman Information seen from the theory of goal attainment, integration, adaptation is already effective in lowering maternal mortality in Brebes Regency. Second, barriers to the implementation of the regulations of the Regent of Brebes No. 026 the year 2015 About community empowerment In Decreasing maternal mortality and infant mortality Through Baby Shaman Information i.e. factor law because Regulation at the village level.
\end{abstract}

Keywords: Effectiveness, Community Empowerment, Maternal and Child Mortality Rate

\begin{abstract}
ABSTRAK
Penelitian ini bertujuan untuk mengetahui dan menganalisis efektivitas Peraturan Bupati Brebes No. 026 Tahun 2015 dan untuk mengetahui dan menganalisis faktor yang menghambat pelaksanaan Peraturan Bupati Brebes No. 026 Tahun 2015. Penelitian ini termasuk kategori penelitian yuridis sosiologis. Data yang diperoleh disajikan dalam bentuk naratif. Berdasarkan pada hasil penelitian dan pembahasan dapat diambil kesimpulan sebagai berikut: Pertama, Peraturan Bupati Brebes No. 026 Tahun 2015 Tentang Pemberdayaan Masyarakat Dalam Penurunan Angka Kematian Ibu dan Angka Kematian Bayi Melalui Maklumat Dukun Bayi dilihat dari teori pencapaian tujuan, integrasi, adaptasi sudah efektif dalam menurunkan Angka Kematian Ibu di Kabupaten Brebes. Kedua, hambatan pelaksanaan Peraturan Bupati Brebes No. 026 Tahun 2015 Tentang Pemberdayaan Masyarakat Dalam Penurunan Angka Kematian Ibu dan Angka Kematian Bayi Melalui Maklumat Dukun Bayi yaitu faktor hukumnya karena belum adanya regulasi di tingkat desa.
\end{abstract}

Kata Kunci : Efektivitas, Pemberdayaan Masyarakat, Angka Kematian Ibu dan Anak

Program Magister IImu Hukum, Universitas Jenderal Soedirman, Email: djraka43@gmail.com 
657 | Jurnal Idea Hukum

Vol. 3 No. 2 Oktober 2017

Magister Hukum Fakultas Hukum Universitas Jenderal Soedirman

\section{A. PENDAHULUAN}

Derajat kesehatan yang optimal bagi seluruh lapisan masyarakat merupakan kewajiban konstitusional yang diemban oleh pemerintah sebagaimana diamanatkan dalam pembukaan Undang-Undang Dasar 1945. Upaya mengoptimalkan derajat kesehatan bagi seluruh lapisan masyarakat menjadi tantangan yang tidak mudah mengingat masih banyaknya masalah kesehatan di Indonesia sebagai negara berkembang. Ditegaskan oleh Hidayah dan Anasari bahwa salah satu ciri negara yang sedang berkembang adalah masalah derajat kesehatan yang masih rendah. Di negara Indonesia rendahnya kesehatan ditandai dengan masih tingginya angka kematian pada ibu. Berdasarkan Survei Demografi dan Kesehatan Indonesia (SDKI) tahun 2012, Angka Kematian Ibu yang berkaitan dengan kehamilan, persalinan, dan nifas sebesar 359 per 100.000 kelahiran hidup. $^{2}$

Angka Kematian lbu di Indonesia masih tinggi dan hal tersebut menjadi salah satu permasalahan kesehatan nasional. Kondisi demikian patut mendapat

Wiwit Hidayah dan Tri Anasari, 2012, "Hubungan Kepatuhan Ibu Hamil Mengkonsumsi Tablet $F e$ dengan Kejadian Anemia di Desa Pageraji Kecamatan Cilongok Kabupaten Banyumas". Jurnal Ilmiah Kebidanan, Vol. 3 No. 2 Edisi Desember 2012. perhatian yang serius karena Angka Kematian Ibu dan Angka Kematian Perinatal merupakan tolok ukur untuk menilai keberhasilan pemeriksaan kesehatan terhadap ibu hamil di suatu negara. ${ }^{3}$ Demikian pula menurut Syafiq bahwa Angka Kematian Ibu merupakan indikator utama derajat kesehatan masyarakat dan ditetapkan sebagai salah satu tujuan Millenium Development Goals (MDGs). ${ }^{4}$

Pemerintah memandang serius masalah Angka Kematian Ibu. Menurut Ririanti, peningkatan Kesehatan Ibu dan Anak (KIA) merupakan salah satu upaya Kementerian Kesehatan RI guna mencapai tujuan pembangunan kesehatan melalui Rencana Pembangunan Jangka Menengah Nasional (RPJMN) 2010-2014 dan mendukung pencapaian MDG's tahun 2015. Tren Angka Kematian Ibu di Indonesia secara nasional

Dwi Sarwani, SR dan Sri Nurlaela, Analisis Faktor Risiko Kematian Ibu, (Studi Kasus di Kabupaten Banyumas), Jurusan Kesehatan Masyarakat Fakultas Kedokteran dan Ilmu-Ilmu Kesehatan Universitas Jenderal Soedirman. Purwokerto 2011

4 Ahmad Syafiq, Angka Kematian Ibu dan Pendidikan Perempuan di Indonesia: Tinjauan Ekologis Provinsial, Makalah Konferensi Infid 2013 "Pembangunan Untuk Semua: Memperjuangkan Kualitas Pemerintah, Hak Asasi Manusia, dan Inklusi dalam Rencana Pembangunan Jangka Menengah 2015-2019", Hotel Royal Kuningan Jakarta, 26-27 November 2013. 
dari tahun 1994 sampai dengan tahun 2007 menunjukkan penurunan yang signifikan. Angka Kematian Ibu di Indonesia tahun 1995 sebesar 390 per 100.000 kelahiran hidup menjadi 228 €per 100.000 kelahiran hidup pada tahun 2007. Namun akibat komplikasi kehamilan atau persalinan yang belum sepenuhnya dapat ditangani, masih terdapat 20.000 ibu yang meninggal setiap tahunnya. Dengan kondisi ini, pencapaian target MDGs terkait penurunan Angka Kematian Ibu akan sulit dicapai. Badan Pusat Statistik memproyeksikan pencapaian Angka Kematian lbu baru mencapai angka 163 per 100.000 kelahiran hidup pada tahun 2015, sedangkan angka tersebut masih jauh dari target RPJMN tahun 2014 sebesar 118 per 100.000 kelahiran hidup apalagi mencapai target MDG's 102 per 100.000 kelahiran hidup tahun $2015 .{ }^{5}$

Salah satu daerah yang tercatat memiliki Angka Kematian Ibu tinggi adalah Kabupaten Brebes. Menurut Dinas Kesehatan Kabupaten Brebes, Angka Kematian Ibu di Kabupaten Brebes Tahun 2009 s.d 2014 bersifat fluktuatif, namun pada tiga tahun terakhir

${ }^{5}$ Mury Ririanti, Determinan Proksi Dalam Gambaran Jumlah Kematian Ibu Berdasatkan Status Maternal di Kabupaten Jember Tahun 2007 - 2011, Prosiding Seminar Nasional Kependudukan, Fakultas Kesehatan Masyarakat Universitas Jember. 2013
(2012 s.d 2014) terus mengalami peningkatan. Menurut data dari Dinas Kesehatan Provinsi Jawa Tengah, daerah peringkat teratas untuk Angka Kematian Ibu tahun 2014 di Jawa Tengah adalah Kabupaten Brebes dengan 73 kasus, Kabupaten Tegal dengan 47 Kasus, Kabupaten Grobogan dengan 43 kasus, Kabupaten Pemalang dengan 40 kasus, Kabupaten Pekalongan dengan 39 kasus, dan Kabupaten Cilacap sebanyak 36 kasus (Keterangan: Perhitungan kasus adalah per 1000 kelahiran hidup). ${ }^{6}$

Tingginya Angka Kematian Ibu berdampak pada peringkat Indeks Pembangunan Manusia Kabupaten Brebes. Menurut data pada "Profil Pembangunan Provinsi Jawa Tengah Tahun 2008-2012" IPM Kabupaten Brebes terendah di Provinsi Jawa Tengah, dengan skor 68,61. Secara nasional IPM Kabupaten Brebes berada di peringkat ke-399. Terkait dengan Angka Kematian Ibu, Kabupaten Brebes menempati peringkat teratas Angka Kematian lbu di Provinsi Jawa Tengah tahun 2014.

Menurut Aeni, kematian ibu merupakan peristiwa kompleks yang disebabkan oleh berbagai penyebab

\footnotetext{
${ }^{6}$ Sri Mulyani. Strategi Menurunkan Angka Kematian Ibu di Kabupaten Brebes (Studi Kasus pada Puskesmas dengan AKI Nihil).. Tesis. Program Studi Manajemen Unsoed,. Purwokerto 2015.
} 
659 | Jurnal Idea Hukum

Vol. 3 No. 2 Oktober 2017

Magister Hukum Fakultas Hukum Universitas Jenderal Soedirman

yang dapat dibedakan atas

determinan dekat, antara, dan jauh.

Determinan dekat yang berhubungan langsung dengan kematian ibu merupakan gangguan obstetrik seperti perdarahan, preeklamsi/ eklamsi, dan infeks atau penyakit yang diderita ibu sebelum atau selama kehamilan yang dapat memperburuk kondisi kehamilan seperti jantung, malaria, tuberkulosis, ginjal, dan acquired immune deficiency syndrome. Determinan dekat secara langsung dipengaruhi oleh determinan antara yang berhubungan dengan faktor kesehatan, seperti status kesehatan ibu, status reproduksi, akses terhadap pelayanan kesehatan, dan perilaku penggunaan fasilitas kesehatan. Determinan jauh berhubungan dengan faktor demografi dan sosiokultural.

Kesadaran masyarakat yang rendah tentang kesehatan ibu hamil, pemberdayaan perempuan yang tidak baik, latar belakang pendidikan, sosial ekonomi keluarga, lingkungan masyarakat dan politik, serta kebijakan secara tidak langsung diduga ikut berperan dalam meningkatkan kematian ibu. ${ }^{7}$ Salah satu penyebab Angka Kematian lbu adalah karena pemanfaatan tenaga non kesehatan, seperti dukun bayi,

\footnotetext{
${ }^{7}$ Nurul Aeni, "Faktor Risiko Kematian Ibu", Jurnal Kesehatan Masyarakat Nasional Vol. 7, No. 10, Mei 2013.
}

dalam menangani persalinan. Hal tersebut merupakan fenomena nyata yang masih dijumpai dalam masyarakat hingga kini. Perkembangan jaman belum sepenuhnya mampu mengeliminasi kepercayaan terhadap dukun bayi. Menurut Aiman keberadaan dukun bayi di masyarakat masih memegang peranan penting. Sebagian warga masyarakat masih mempercayakan pertolongan persalinan oleh dukun bayi. ${ }^{8}$

$$
\text { Masyarakat }
$$

Kabupaten

Brebes masih memiliki kepercayaan terhadap dukun bayi. Pemanfaatan dukun bayi untuk menangani persalinan pada tahun 2014 bahkan meningkat tajam dibandingkan tahun 2013, yaitu dari 145 menjadi 572. Kondisi tersebut menjadi sebuah ironi di tengah gencarnya upaya Pemerintah Kabupaten Brebes untuk mengarahkan pelayanan ibu hamil hanya dilakukan pada fasilitas kesehatan. Selain itu, kebijakan dari pemerintah pusat juga telah menggariskan bahwa pelayanan ibu hamil, khususnya untuk persalinan, harus dilakukan di fasilitas kesehatan.

Kepercayaan masyarakat Kabupaten Brebes kepada dukun bayi merupakan fenomena yang

\footnotetext{
${ }^{8}$ Ummu Aiman. 2013. Maklumat Dukun Bayi Turunkan Angka Persalinan Dengan Dukun Bayi. http://celotehlarangan.com. Diakses tanggal 6 Desember 2016.
} 
menarik di tengah gencarnya pembangunan kesehatan yang dilakukan pemerintah. Untuk mengatasi hal tersebut, sekaligus sebagai upaya untuk menurunkan Angka Kematian lbu, maka Pemerintah Kabupaten Brebes meluncurkan kebijakan Maklumat Dukun Bayi, yang ditetapkan dengan Peraturan Bupati Brebes No. 026 Tahun 2015 tentang Pemberdayaan Masyarakat Dalam Penurunan Angka Kematian Ibu dan Angka Kematian Bayi Melalui Maklumat Dukun Bayi. Isi kebijakan yaitu kesediaan dukun bayi untuk melakukan beberapa hal sebagai berikut.

1) Membantu merencanakan persalinan dan pencegahan komplikasi.

2) Membantu mengantarkan ibu hamil untuk pergi periksa ke bidan atau fasilitas pelayanan kesehatan.

3) Membantu mengantarkan ibu hamil yang beresiko tinggi kepada bidan atau fasilitas pelayanan kesehatan.

4) Membantu mengantarkan ibu hamil yang akan melahirkan kepada bidan atau fasilitas pelayanan kesehatan.

5) Tidak akan menolong persalinan.

6) Membantu merawat ibu dan bayi setelah proses persalinan di fasilitas pelayanan kesehatan.

7) Bersedia menerima sanksi, apabila tidak menepati janji maklumat ini.

Adanya kebijakan tersebut menjadikan dukun bayi tidak diperbolehkan lagi untuk membantu persalinan. Dukun bayi yang sudah menandatangani maklumat tetapi terbukti masih menangani persalinan dapat dikenakan sanksi, yaitu denda. Berdasarkan hasil hasil musyawarah dan kesepakatan antara aparatur pemerintah desa, pemerinah kecamatan, petugas dinas kesehatan dan warga masyarakat di Kabupaten Brebes, denda tersebut ditetapkan sebesar Rp 1 juta. Sanksi tersebut cukup berat dan berpotensi mematikan mata pencaharian warga masyarakat yang berprofesi sebagai dukun bayi.

Dalam kenyataannya, pemanfaatan jasa dukun bayi masih saja terjadi di Kabupaten Brebes, mengingat masih ada pelanggaran pertolongan persalinan, maka peneliti tertarik mengkaji lebih lanjut tentang Peraturan Bupati Brebes No. 026 Tahun 2015, sehingga peneliti mengambil judul "Efektivitas Peraturan Bupati Brebes Nomor 026 Tahun 2015 Tentang Pemberdayaan Masyarakat Dalam Penurunan Angka Kematian Ibu Dan Angka Kematian Bayi Melalui Maklumat Dukun Bayi”. Penelitian ini penting untuk dilakukan guna memberikan solusi kepada Pemerintah Kabupaten Brebes dalam menurunkan Angka Kematian Ibu.

\section{B.METODE PENELITIAN}

Penelitian ini termasuk kategori penelitian yuridis sosiologis. Ronny Hanitijo Soemitro berpendapat bahwa 
661 | Jurnal Idea Hukum

Vol. 3 No. 2 Oktober 2017

Magister Hukum Fakultas Hukum Universitas Jenderal Soedirman

dalam penelitian yuridis

sosiologis hukum tidak

dikonsepsikan sebagai suatu

gejala normatif yang mandiri

(otonom), tetapi sebagai suatu

institusi sosial yang dikaitkan

secara riil dengan variabel-

variabel sosial yang lain dan

dengan menggunakan analisis

yang bersifat empiris-kuantitatif

atau disebut juga penelitian

hukum sosiologis (Social legard research). ${ }^{9}$ Sumber data yang

dipakai adalah Bahan Hukum

Primer

Bahan Hukum Sekunder, dan

Bahan Hukum Tersier.

Pengumpulan data primer dilakukan wawancara dengan dukun bayi, ibu bersalin yang menggunakan jasa dukun bayi, bidan/ petugas Puskesmas, dan petugas Dinas Kesehatan Kabupaten Brebes. Data yang telah terkumpul, selanjutnya dianalisa dengan menggunakan analisis kualitatif.

\section{C.HASIL PENELITIAN DAN PEMBAHASAN}

1. Efektivitas

Peraturan

Bupati Brebes No. 026 Tahun 2015

Hak atas pelayanan dan perlindungan kesehatan bagi ibu dan anak merupakan hak dasar sebagaimana termaktub dalam Undang-undang Dasar 1945. Pasal

9 Soemitro Ronny Hanitijo, Metodologi Penelitian Hukum, Ghalia Indonesia, Jakarta, 1990,hlm. 35.
28 H UUD 1945 menentukan bahwa setiap orang hidup sejahtera lahir dan batin bertempat tinggal dan mendapat lingkungan hidup yang baik dan sehat serta berhak memperoleh pelayanan kesehatan. Pasal 34 ayat (3) UUD 1945 menentukan bahwa negara bertanggung jawab atas penyediaan fasilitas pelayanan kesehatan dan fasilitas pelayanan umum yang layak. Pencantuman hak terhadap pelayanan kesehatan tersebut, tidak lain bertujuan untuk menjamin hakhak kesehatan yang fundamental seperti tertuang dalam Declaration of Human Right 1948, bahwa health is a fundamental human right. Beberapa konvensi internasional yang ditandatangani oleh pemerintah Indonesia yaitu UU No. 7 Tahun 1984 tentang Ratifikasi Penghapusan segala bentuk diskriminasi terhadap perempuan, kesepakatan konvensi internasional tentang perempuan di Beijing tahun $1995 .^{10}$

\section{Millenium Development}

Goals (MDGs) merupakan komitmen nasional dan global dalam upaya lebih menyejahterakan masyarakat melalui pengurangan kemiskinan

${ }^{10}$ Tedi Sudrajat dan Agus Mardiyanto, "Hak Atas Pelayanan dan Perlindungan Kesehatan Ibu dan Anak (Implementasi Kebijakan di Kabupaten Banyumas)", Jurnal Dinamika Hukum, Vol. 12 No. $2 \mathrm{Mei}$ 2012, Purwokerto: Fakultas Hukum Universitas Jenderal Soedirman, hlm. 261-262 
dan kelaparan, pendidikan, pemberdayaan perempuan, kesehatan dan kelestarian lingkungan. Sebagian besar pencapaian MDGs Indonesia sudah sesuai dengan rencana target yang ditetapkan, namun demikian, masih ada beberapa target MDGs yang memerlukan upaya keras untuk mencapainya, salah satunya adalah menurunkan Angka Kematian Ibu (AKI).

Permasalahan kesehatan ibu dan anak menjadi penting karena angka kematian ibu di Indonesia masih tinggi dan memerlukan perhatian serta upaya khusus untuk menurunkannya. Badan Pusat Statistik memproyeksikan pencapaian Angka Kematian Ibu baru mencapai angka 163 per 100.000 kelahiran hidup pada tahun 2015, sedangkan angka tersebut masih jauh dari target RPJMN tahun 2014 sebesar 118 per 100.000 kelahiran hidup apalagi mencapai target MDG's 102 per 100.000 kelahiran hidup tahun $2015 .{ }^{11}$

Data yang diperoleh dari Profil Kesehatan Kabupaten Brebes Tahun tahun 2014 diketahui bahwa angka kematian bayi mengalami penurunan bila dibandingkan tahun

${ }^{11}$ Mury Ririanti, Determinan Proksi Dalam Gambaran Jumlah Kematian Ibu Berdasatkan Status Maternal di Kabupaten Jember Tahun 2007 - 2011, Prosiding Seminar Nasional Kependudukan, Fakultas Kesehatan Masyarakat Universitas Jember. 2013,
2013 dan bila berdasarkan target MDG (Millenium Development Goals) ke -4 tahun 2015 yaitu 23 per 1000 kelahiran hidup, berarti angka kematian bayi di Kabupaten Brebes masih dibawah target tersebut. Berdasarkan laporan bulanan puskesmas Angka Kematian Ibu (AKI) untuk tahun 2014 sebesar 218,20 /100.000 kelahiran hidup atau sebanyak 73 kasus, mengalami peningkatan bila dibandingkan dengan angka kematian ibu pada tahun 2013 sebesar 184,4,0/100.000 kelahiran hidup atau sebanyak 61 kasus. Pertolongan persalinan mempunyai peranan yang cukup besar dalam penurunan angka kematian bayi dan kematian ibu. Berdasarkan laporan Puskesmas pada tahun 2014 pertolongan persalinan oleh tenaga kesehatan sebanyak 32.825 dari 34.729 ibu bersalin atau $94,52 \%$.

Kesehatan ibu yang disebut juga sebagai kesehatan maternal, merupakan bagian dari kesehatan reproduksi perempuan yang mencakup kesehatan reproduksi sejak remaja, saat sebelum hamil, hamil, persalinan, dan sesudah melahirkan. Upaya penurunan angka morbiditas ibu dan anak menekankan pada penyediaan dan pemanfaatan pelayanan kesehatan. Pelayanan kesehatan pada ibu hamil juga disebut Antenatal Care (ANC) yaitu pelayanan kesehatan oleh tenaga profesional untuk ibu 
hamil selama masa kehamilannya yang dilaksanakan sesuai dengan standar pelayanan antenatal yang di tetapkan. Pemeriksaan Antenatal Care (ANC) adalah pemeriksaan kehamilan untuk mengoptimalkan kesehatan mental dan fisik ibu hamil, hingga mampu menghadapi persalinan, kala nifas, persiapan pemberiaan $\mathrm{ASI}$ dan kembalinya kesehatan reproduksi secara wajar. $^{12}$

Hakikatnya pelayanan kesehatan yang dilakukan oleh tenaga medis diarahkan pada aspek keserasian dan keseimbangan atas penanganan dan dampak yang ditimbulkan. Hal ini merupakan inti dari berbagai kegiatan dalam menyelenggarakan praktik medis untuk mencegah masalah hukum yang timbul dalam kegiatan masalah tersebut. ${ }^{13}$ Keterlibatan pemerintah sebagai penanggung jawab di bidang pembangunan dalam rangka penyelenggaraan pembangunan kesehatan masyarakat merupakan salah satu unsur kesejahteraan umum yang merupakan tujuan nasional yang harus diwujudkan sesuai dengan cita-cita Bangsa

12 C. Manuaba, Gawat-Darurat ObstetriGinekologi dan Obstetri-Ginekologi Sosial untuk Profesi Bidan. Penerbit Buku Kedokteran EGC. Jakarta. 2008. hlm. 110

${ }^{13}$ Umi Rozah "Pertanggungjawaban Pidana Dokter Dalam Malpraktik Medis", Jurnal Masalah-Masalah Hukum, Vol. 33 No. 3 2004, Semarang: Fakultas Hukum UNDIP, hlm. 214-224
Indonesia.

Pelaksanaan otonomi daerah telah membawa perubahan yang besar dalam berbagai aspek kehidupan masyarakat di daerah. Pemberian otonomi luas kepada daerah tersebut diarahkan untuk mempercepat terwujudnya kesejahteraan masyarakat melalui peningkatan pelayanan, pemberdayaan dan peran serta masyarakat. Di samping itu melalui otonomi luas, daerah diharapkan mampu meningkatkan daya saing dengan memperhatikan prinsip demokrasi, pemerataan, keadilan, keistimewaan dan kekhususan serta potensi keanekaragaman dalam sistem Negara Kesatuan Republik Indonesia.

Pemerintah daerah memiliki peran penting dalam mendukung penyelenggaraan pembangunan kesehatan nasional. Konsepsi peran mengandaikan seperangkat harapan untuk bertindak dengan cara-cara tertentu dan mengharapkan orang lain untuk bertindak dengan caracara tertentu pula. ${ }^{14}$ Pemerintahan Daerah adalah daerah otonom diselenggarakan secara bersamasama oleh seorang kepala wilayah yang sekaligus merupakan kepala daerah otonom. Pemerintah daerah memperoleh pelimpahan wewenang pemerintahan umum dari pusat,

14 Paul B Horton. Dan Chester L. Hunt. Sosiologi. Jakarta: Erlangga. 2008.hlm. 118-119 
yang meliputi wewenang mengambil setiap tindakan untuk kepentingan rakyat berdasarkan peraturan perundangan yang berlaku. Urusan pemerintahan umum yang dimaksud sebagian berangsur-angsur diserahkan kepada pemerintah daerah sebagai urusan rumah tangga daerahnya, kecuali yang bersifat nasional untuk menyangkut kepentingan umum yang lebih luas.

\begin{tabular}{cc}
\multicolumn{2}{c}{ Berkaitan dengan } \\
pelaksanaan otonomi daerah
\end{tabular} penyelenggaraan pemerintahan daerah yang demokratis dan akuntabel merupakan konsekuensi logis otonomi daerah yang semestinya memungkinkan semakin dekatnya pelayanan pemerintahan daerah kepada masyarakat. Penyelesaian masalah-masalah di daerah menjadi lebih terfokus dan mandiri. Partisipasi masyarakat menjadi lebih luas dalam pembangunan daerah. Masyarakat melakukan pengawasan lebih intensif terhadap penyelenggaraan pemerintahan daerah.

$$
\text { Pemerintah }
$$

Daerah

Kabupaten Brebes telah mengeluarkan Peraturan Bupati Brebes No. 026 Tahun 2015 Tentang Pemberdayaan Masyarakat Dalam Penurunan Angka Kematian Ibu dan Angka Kematian Bayi Melalui Maklumat Dukun Bayi. Kebijakan yang diambil Pemerintah Kabupaten Brebes tersebut dalam perjalanannya juga didukung dengan keluarnya Peraturan

Gubernur Jawa Tengah Nomor 17 Tahun $2016 \quad$ Tentang Penyelenggaraan Kesehatan lbu Dan Anak di Provinsi Jawa Tengah. Pertimbangan dikeluarkannya Peraturan Gubernur tersebut adalah dalam rangka pemenuhan hak hidup sehat bagi ibu dan anak, telah dilakukan upaya peningkatan kesehatan, namun belum memberikan hasil yang maksimal dimana angka kematian ibu dan bayi masih tinggi, sehingga diperlukan upaya yang optimal guna percepatan penurunan angka kematian ibu dan bayi.

Efektivitas hukum banyak menyangkut kepentingan para warga masyarakat sebagai subyek atau pemegang peranan. Hukum menentukan peranan apa yang sebaiknya dilakukan oleh para subyek hukum, dan hukum semakin efektif apabila peranan yang dijalankan oleh para subyek hukum semakin mendekati apa yang telah ditentukan dalam hukum. Adanya suatu jarak peranan mungkin disebabkan hukum hanya berlaku secara yuridis, yang menjadi pertanda bahwa hukum tersebut mengalami hambatan-hambatan dalam efektivitasnya. ${ }^{15}$ Kebijakan Pemerintah Daerah Kabupaten Brebes dengan dikeluarkannya

15 Soerjono Soekanto. Kegunaan Sosiologi Hukum Bagi Kalangan Hukum. Alumni. Bandung. 1976. h. 45 
665 | Jurnal Idea Hukum

Vol. 3 No. 2 Oktober 2017

Magister Hukum Fakultas Hukum Universitas Jenderal Soedirman

Peraturan Bupati Brebes No. 026

Tahun 2015 diharapkan dapat mencapai tujuan yang diharapkan yaitu dapat menurunkan Angka Kematian Ibu.

Menurut Duncan, efektivitas juga dapat diukur melalui beberapa parameter, yaitu pencapaian tujuan, integrasi, dan adaptasi. ${ }^{16}$ Pencapaian tujuan merupakan keseluruhan upaya pencapaian tujuan yang harus dipandang sebagai sebuah proses. Oleh karena itu agar pencapaian seluruh tujuan akhir semakin terjamin, diperlukan pentahapan baik dalam artian pentahapan dalam pencapaian bagian-bagiannya maupun pentahapan dalam arti periodisasinya. Selain itu Steers menambahkan bahwa dalam penetapan tujuan meliputi identifikasi tujuan organisasi yang berlaku umum dan penetapan bagaimana berbagai bagian, kelompok dan individu dapat memberikan sumbangannya bagi tujuan yang ditetapkan. Pencapaian tujuan terdiri dari beberapa faktor yakni kurun waktu dan sasaran yang merupakan target kongkrit.

Jika dilihat dari data hasil penelitian pada Gambar 1 diketahui bahwa dapat dikatakan bahwa Peraturan Bupati Brebes No. 026

${ }^{16}$, Richard M Steers., Perilaku Organisasi (Kaidah Perilaku), Terjemahan: Magdalena Jamin, Erlangga, Jakarta. 1985, hlm. 87
Tahun 2015 sudah cukup efektif dalam menurunkan Angka Kematian Ibu di Kabupaten Brebes. Namun demikian, diharapkan pada tahuntahun mendatang masih dapat diturunkan lagi, yang diantaranya dengan memastikan seluruh persalinan ditolong oleh petugas kesehatan dan dilakukan di tempat fasilitas kesehatan.

Menurut Undang-Undang No 36 Tahun 2009 tentang Kesehatan, tenaga kesehatan adalah setiap orang yang mengabdikan diri dalam bidang kesehatan serta memiliki pengetahuan dan/atau keterampilan melalui pendidikan di bidang kesehatan yang untuk jenis tertentu memerlukan kewenangan untuk melakukan upaya kesehatan. Tenaga kesehatan adalah seseorang yang bertanggung jawab dalam memberikan pelayanan kesehatan kepada individu, keluarga dan masyarakat. Tenaga kesehatan berdasarkan pekerjaannya adalah tenaga medis, dan tenaga paramedis seperti tenaga keperawatan, tenaga kebidanan, tenaga penunjang medis dan lain sebagainya. ${ }^{17}$

Faktor berikutnya yang perlu dicermati adalah faktor integrasi yang menyangkut proses sosialisasi. Ukuran yang digunakan adalah tingkat kemampuan organisasi untuk

17 A.A. Gde Muninjaya. Manajemen Kesehatan. Jakarta: Penerbit Buku Kedokteran EGC. 2004. hlm. 220-234. 


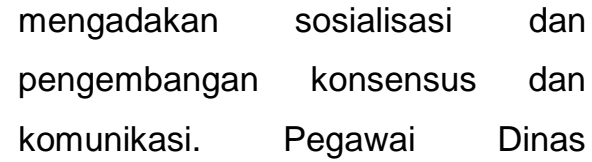

Kesehatan Kabupaten Brebes sudah mengetahui dan memahami dengan baik tentang Peraturan Bupati Brebes No. 026 Tahun 2015. Bidan desa juga sudah mendapatkan sosialisasi dari dinas, sehingga mereka dapat meneruskan kepada kelompok sasaran yaitu para dukun bayi termasuk ibu hamil.

Informasi dari bidan desa membenarkan informasi yang disampaikan oleh pegawai Dinas Kesehatan Kabupaten Brebes. Bidan desa mendapatkan sosialisasi dari dinas maupun dalam kegiatan organisasi Ikatan Bidan Indonesia (IBI). Sementara informasi yang diberikan oleh dukun bayi juga menyatakan mereka sudah mendapatkan penjelasan dari bidan desa tentang peraturan tersebut. Dilihat dari ukuran faktor integrasi, maka dapat dikatakan Peraturan Bupati Brebes No. 026 Tahun 2015 sudah efektif.

Adapun faktor berikutnya adalah adaptasi. Adaptasi adalah kemampuan organisasi untuk menyesuaikan diri dengan lingkungannya. Dalam penelitian efektivitas selalu ditekankan bahwa kemampuan organisasi menyesuaikan diri pada lingkungan yang berubah secara berhasil merupakan ciri utama organisasi yang efektif. Faktor ini menyangkut proses pengadaan sarana dan prasarana serta pengisian tenaga kerja.

Berdasarkan data yang diperoleh dari Dinas Kesehatan Kabupaten Brebes diketahui bahwa Puskesmas sebagai tempat pelayanan kesehatan dasar, telah ada di semua kecamatan Kecamatan) di Kabupaten Brebes. Jumlah Puskesmas di Kabupaten Brebes adalah 38 unit dan 18 unit diantaranya adalah Puskesmas rawat inap. Jumlah Puskesmas pembantu sebanyak 59 unit dan Puskesmas keliling 56 buah dengan Pos Kesehatan Desa (PKD) sebanyak 228 unit. Jumlah BP/Klinik sebanyak 6 unit. Rasio sedangkan praktek dokter perorangan sebanyak 49 unit. Pelayanan kesehatan rujukan di Kabupaten Brebes dilaksanakan oleh 11 (sembilan) Rumah Sakit Umum yang terdiri dari 2 (dua) Rumah Sakit Umum milik Pemerintah Daerah dan 7 (tujuh) Rumah Sakit swasta, 1 (satu) Rumah Sakit Khusus Ibu dan Anak serta 1 (satu) Rumah Sakit Bersalin. Jumlah tenaga kesehatan yaitu bidan di Kabupaten Brebes sebanyak 874 atau 49 per 100.000 penduduk, Dokter umum dan spesialis sebanyak 279 orang atau 16 per 100.000 penduduk. Adapun untuk dokter gigi dan spesialis gigi terdapat 23 dokter atau 1 per 100.000 penduduk.

Berdasarkan pada data-data 
667 | Jurnal Idea Hukum

Vol. 3 No. 2 Oktober 2017

Magister Hukum Fakultas Hukum Universitas Jenderal Soedirman

tersebut di atas, maka dapat dikatakan bahwa Peraturan Bupati Brebes No. 026 Tahun 2015 sudah efektif dalam menurunkan Angka Kematian Ibu (AKI) dilihat dari aspek pencapaian tujuan, integrasi dan adaptasi. Dilihat dari pencapaian tujuan, jumlah Angka Kematian Ibu (AKI) dari tahun 2014 - 2016 cenderung menurun. Pada aspek integrasi, Peraturan Bupati Brebes No. 026 Tahun 2015 sudah disosialisasikan kepada kelompok sasaran yaitu dukun bati oleh petugas kesehatan baik di tingkat kabupaten, kecamatan dan desa. Adapun dilihat dari aspek adaptasi, Pemerintah Daerah dalam hal ini Dinas Kesehatan telah memiliki sejumlah fasilitas pelayanan yang dibutuhkan untuk pertolongan persalinan mulai dari keberadaan rumah sakit negeri dan swasta, Puskesmas di tingkat kecamatan dan Pos Kesehatan Desa (PKD di tingkat desa termasuk Balai Pengobatan/Klinik dan juga ketersediaan tenaga kesehatan yaitu dokter dan bidan yang memadai.

2. Faktor yang menghambat pelaksanaan Peraturan Bupati Brebes No. 026 Tahun 2015

Peraturan Bupati Brebes No. 026 Tahun 2015 sudah efektif dalam menurunkan Angka Kematian lbu (AKI), namun demikian, dengan makin meningkatnya jumlah penduduk usia produktif akan meningkatkan jumlah kehamilan dan persalinan yang tentunya akan berisiko terhadap risiko kematian ibu. Oleh karena itu, pencapaian Angka Kematian Ibu yang cenderung menurun tetap harus diimbangi dengan penyelenggaraan pelayanan kesehatan ibu dan anak yang lebih baik.

Pelaksanaan Peraturan Bupati Brebes No. 026 Tahun 2015 sampai saat ini bukan berarti dapat berjalan tanpa adanya hambatan. Angka Kematian Ibu tetap masih dapat diturunkan jika Peraturan Bupati Brebes No. 026 Tahun 2015 dapat dilaksanakan dengan lebih baik, terutama dalam memastikan seluruh persalinan ditolong oleh tenaga kesehatan dan dilakukan di tempat fasilitas pelayanan kesehatan.

Berdasarkan pada hasil penelitian diketahui masih adanya pertolongan persalinan yang dilakukan oleh dukun bayi. Hal ini bukan berarti memastikan pertolongan persalinan oleh dukun bayi berujung pada kematian ibu, namun risiko kematian ibu lebih tinggi dibandingkan jika ibu bersalin ditolong oleh tenaga kesehatan.

Mortalitas dan morbiditas pada wanita hamil dan bersalin adalah masalah besar di negara berkembang. Negara berkembang menyumbang $99 \%$ dari total 
kematian ibu. ${ }^{18}$ Kematian saat melahirkan biasanya menjadi faktor utama mortalitas. Kematian ibu ini biasanya disebut kematian maternal yaitu kematian perempuan hamil atau kematian dalam 42 hari setelah berakhirnya kehamilan tanpa mempertimbangkan umur dan jenis kehamilan, sebagai komplikasi persalinan atau nifas, dengan penyebab terkait atau diperberat oleh kehamilan dan manajemen kehamilan, tetapi bukan karena kecelakaan. ${ }^{19}$

Penyebab kematian maternal dapat dikategorikan berdasarkan Tiga Terlambat (The Three Delays). Terlambat Pertama (1) adalah terlambat memutuskan untuk pencarian layanan kesehatan; Terlambat Kedua (2) adalah terlambat mengidentifikasi dan mencapai tempat layanan kesehatan; dan Terlambat Ketiga (3) adalah terlambat menerima layanan yang memadai dan tepat. Terlambat 1 berhubungan dengan masalah kultural seperti status perempuan sebagai penentu kebijakan dan pengambil keputusan, juga dipengaruhi oleh aksesibilitas terhadap layanan kesehatan dan

${ }^{18}$ Gutierrez. R Gustavo, Vera.E, de Lean P, Vargas LF. "Risk Factors of Maternal Death in Mexico". Journal Birth, Volume 34, 2007. pp. 21-25.

${ }^{19}$ Kaddour C, Souissi R, et al. "Causes and Risk Factors of Maternal Mortality in the ICU", Critical Care, Volume 12 suppl 2. 2008. kualitas layanan yang diberikan. Akses (terutama geografis dan finansial) juga mempengaruhi terjadinya Terlambat 2; sedangkan Terlambat 3 terutama dipengaruhi oleh kualitas layanan kesehatan. ${ }^{20}$

Direktorat Bina Kesehatan Ibu Kementerian Kesehatan RI berdasarkan Riset Kesehatan Dasar (Riskesdas) 2010 mengkategorikan faktor penyebab AKI di Indonesia dalam dua kelompok, yaitu faktor penyebab langsung dan tidak langsung. Faktor penyebab langsung kematian ibu di Indonesia masih didominasi oleh perdarahan, hipertensi/eklampsia, dan infeksi. Faktor tidak langsung penyebab kematian ibu karena masih banyaknya kasus 3 Terlambat dan 4 Terlalu.

\section{Terlambat:}

1. Terlambat mengenali tanda bahaya persalinan dan mengambil keputusan.

2. Terlambat dirujuk ke fasilitas pelayanan kesehatan

3. Terlambat ditangani oleh tenaga kesehatan di fasilitas pelayanan kesehatan.

\section{Terlalu}

${ }^{20}$ Ahmad Syafiq, Angka Kematian Ibu dan Pendidikan Perempuan di Indonesia: Tinjauan Ekologis Provinsial, Makalah Konferensi Infid 2013 "Pembangunan Untuk Semua: Memperjuangkan Kualitas Pemerintah, Hak Asasi Manusia, dan Inklusi dalam Rencana Pembangunan Jangka Menengah 20152019”, Hotel Royal Kuningan Jakarta, 26-27 November 2013. 
1. Terlalu tua hamil (di atas usia 35 tahun) sebanyak $27 \%$

2. Terlalu muda untuk hamil (di bawah usia 20 tahun) sebanyak $2,6 \%$

3. Terlalu banyak (jumlah anak lebih dari 4) sebanyak $11,8 \%$

4. Terlalu dekat (jarak antar kelahiran kurang dari 2 tahun) Menurut Soerjono Soekanto, masalah penegakan hukum yang sebenarnya pada faktor - faktor yang mungkin mempengaruhinya, yaitu faktor hukumnya sendiri, faktor penegak hukum dan faktor sarana atau fasilitas yang mendukung penegakan hukum, faktor masyarakat dan faktor kebudayaan.

a. Faktor Hukumnya

Dilihat dari faktor hukumnya, yaitu Peraturan Bupati Brebes No. 026 Tahun 2015 memberikan perlindungan kepada ibu dan bayi untuk mendapatkan pelayanan persalinan yang aman. Peraturan Menteri Kesehatan Republik Indonesia Nomor 97 Tahun 2014 Tentang Pelayanan Kesehatan Masa Sebelum Hamil, Masa Hamil, Persalinan, dan Masa Sesudah Melahirkan, Penyelenggaraan Pelayanan Kontrasepsi, Serta Pelayanan Kesehatan Seksual pada Pasal 14 ayat (1) secara jelas mengatur bahwa persalinan harus dilakukan di fasilitas pelayanan kesehatan.
Selanjutnya dalam Pasal 46 ayat (1) disebutkan bahwa dalam rangka membantu mempercepat pencapaian derajat kesehatan ibu yang optimal diperlukan peran serta masyarakat baik secara perseorangan maupun terorganisasi.

Peraturan Bupati Brebes No. 026 Tahun 2015 mengatur tentang sanksi yang disebutkan dalam Pasal 8 ayat (4) yaitu: "Sanksi pelanggaran terhadap maklumat dukun bayi ditetapkan oleh desa melalui musyawarah masyarakat desa". Meskipun demikian, sanksi tersebut belum diatur secara jelas. Kecamatan maupun desa belum mengakomodir peraturan bupati di tingkat kecamatan dan desa. Oleh karena itu, regulasi di tingkat desa melalui keberadaan peraturan desa perlu didorong agar dapat meningkatkan keberhasilan pelaksanaan Peraturan Bupati Brebes No. 026 Tahun 2015.

Jika dilihat dari faktor hukumnya, maka belum adanya regulasi di tingkat desa berupa Peraturan Desa yang dibuat oleh Kepala Desa bersama dengan Badan Permusyawaratan Desa (BPD) menyebabkan pemberian sanksi bagi dukun bayi yang tidak mematuhi aturan yang 
diatur dalam Peraturan Bupati

Brebes No. 026 Tahun 2015

tidak dapat ditegakkan.

Berdasarkan pada kondisi

tersebut, maka upaya agar

Peraturan Bupati Brebes No.

026 Tahun 2015 dapat dipatuhi

oleh dukun bayi adalah dengan

memberikan penjelasan yang

dilakukan terus menerus

tentang manfaat pertolongan

persalinan oleh tenaga

kesehatan yang dilakukan oleh tenaga kesehatan. Dukun bayi

diberi penjelasan tentang risiko

yang dapat terjadi akibat

pertolongan persalinan yang

dilakukan di rumah dengan fasilitas yang terbatas dan

tidak dilakukan oleh tenaga

kesehatan.

b. Faktor Penegak Hukum

Dilihat dari faktor penegak hukum, Peraturan Bupati Brebes No. 026 Tahun 2015 mengatur adanya kegiatan pengawasan, pemantauan, pelaporan dan evaluasi. Peraturan Bupati Brebes No. 026 Tahun 2015 mengatur tentang pengawasan sebagaimana disebutkan dalam Pasal 9 ayat (1) yaitu: "Bupati melaksanakan pengawasan melalui SKPD dan kecamatan". Kegiatan pengawasan sudah dilakukan dalam rangka pelaksanaan peraturan tersebut, namun petugas kesehatan hanya dapat mengingatkan dan menghimbau agar pertolongan persalinan dilakukan oleh petugas kesehatan dan dilakukan di tempat pelayanan kesehatan. Terkait dengan hal tersebut, maka sudah diupayakan dengan adanya Pelayanan Obstetri Neonatal Emergensi Dasar (PONED). PONED dilaksanakan di tingkat puskesmas, dan menerima rujukan dari tenaga atau fasilitas kesehatan di tingkat desa atau masyarakat dan merujuk ke rumah sakit.

Kegiatan pengawasan sebagai bagian dari penegakan hukum yang menyangkut penegakan peraturan daerah dilakukan oleh Satuan Polisi Pamong Praja (Satpol PP). Peraturan Pemerintah Republik Indonesia Nomor 6 Tahun 2010 Tentang Satuan Polisi Pamong Praja menjelaskan bahwa Satuan Polisi Pamong Praja, yang selanjutnya disingkat Satpol PP, adalah bagian perangkat daerah dalam penegakan Peraturan Daerah dan penyelenggaraan ketertiban umum dan ketenteraman masyarakat.

Kegiatan penegakan hukum oleh SKPD yang dalam hal ini oleh Satpol PP belum dapat berjalan dengan baik akibat belum adanya regulasi di 
671 | Jurnal Idea Hukum

Vol. 3 No. 2 Oktober 2017

Magister Hukum Fakultas Hukum Universitas Jenderal Soedirman

tingkat desa. Hal ini seperti yang

diatur dalam Peraturan Bupati

Brebes No. 026 Tahun 2015

mengatur tentang sanksi yang

disebutkan dalam Pasal 8 ayat

(4) yang telah disebutkan

sebelumnya ditetapkan oleh

desa melalui musyawarah

masyarakat desa.

Jika dilihat dari aparatur pemerintahan desa, jumlah perangkat desa di setiap desa rata-rata berjumlah 14 orang.

Tingkat pendidikan perangkat desa juga sudah cukup baik, rata-rata berpendidikan SMA dan untuk sekretaris desa berpendidikan Perguruan Tinggi (DIII, S1). Selain itu di setiap desa sudah terdapat Badan Permusyawaratan Desa (BPD, yang anggotanya terdiri dari para tokoh masyarakat dengan pendidikan rata-rata SMP ke atas.

Dilihat dari keberadaan perangkat desa dan Badan Permusyawaratan Desa (BPD) yang diantaranya bertugas untuk menyusun peraturan desa, pada dasarnya sudah memadai. Oleh karena itu, dilihat dari faktor penegak hukum di tingkat desa sudah bukan menjadi faktor yang menghambat pelaksanaan Peraturan Bupati Brebes No. 026 Tahun 2015.

Adapun untuk kegiatan pemantauan secara berkala sudah dilakukan oleh pihak puskesmas, camat dan kepala desa yang melibatkan bidan desa dan juga dukun bayi. Bidan setiap bulan membuat laporan kegiatan program kesehatan ibu dan anak termasuk keluarga berencana agar dapat melakukan evaluasi keberhasilan pelaksanaan program yang mendukung upaya menekan Angka kematian Ibu (AKI).

c. Faktor sarana atau fasilitas yang mendukung penegakan hukum

Faktor risiko yang berkaitan dengan kematian ibu bersalin akibat terlambat dirujuk ke fasilitas pelayanan kesehatan dan terlambat ditangani oleh tenaga kesehatan di fasilitas pelayanan kesehatan yang termasuk dalam faktor sarana atau fasilitas yang mendukung penegakan hukum.

Data fasilitas pelayanan kesehatan yang ada di Kabupaten Brebes diketahui bahwa Puskesmas sebagai tempat pelayanan kesehatan dasar telah ada di semua kecamatan (17 Kecamatan) di Kabupaten Brebes. Jumlah Puskesmas di Kabupaten Brebes adalah 38 unit dan 18 unit diantaranya adalah Puskesmas rawat inap. Jumlah Puskesmas pembantu sebanyak 
59 unit dan Puskesmas keliling 56 buah dengan Pos Kesehatan Desa (PKD) sebanyak 228 unit. Jumlah BP/Klinik sebanyak 6 unit. Rasio sedangkan praktek dokter perorangan sebanyak 49 unit. Pelayanan kesehatan rujukan di Kabupaten Brebes dilaksanakan oleh 11 (sembilan) Rumah Sakit Umum yang terdiri dari 2 (dua) Rumah Sakit Umum milik Pemerintah Daerah dan 7 (tujuh) Rumah Sakit swasta, 1 (satu) Rumah Sakit Khusus Ibu dan Anak serta 1 (satu) Rumah Sakit Bersalin.

Sesuai dengan yang diatur dalam Peraturan Menteri Kesehatan Republik Indonesia Nomor 75 Tahun 2014 Tentangpusat Kesehatan Masyarakat pada Pasal 9 ayat (1) bahwa Puskesmas harus didirikan pada setiap kecamatan. Selanjutnya dalam ayat (2) disebutkan bahwa dalam kondisi tertentu, pada 1 (satu) kecamatan dapat didirikan lebih dari 1 (satu) Puskesmas. Keberadaan puskesmas yang sudah ada di setiap puskesmas dan terdapat beberapa kecamatan yang terdapat lebih dari satu puskesmas menunjukkan fasilitas pelayanan kesehatan yang ada sudah sesuai dengan ketentuan yang berlaku.

Faktor geografis menyangkut keberadaan tempat tinggal penduduk yang jauh dari sarana pelayanan kesehatan. Upaya ini secara perlahan telah dilakukan pembenahan dengan dibukanya puskesmas pembantu untuk mendekatkan fasilitas pelayanan kesehatan kepada masyarakat. Fasilitas pelayanan kesehatan dan kualitas sumberdaya manusia kesehatan juga terus ditingkatkan. Pengaturan tentang persyaratan pendidikan tenaga kesehatan, khususnya bidan juga terus digalakkan termasuk upaya melibatkan organisasi profesi bidan (Ikatan Bidan Indonesia) untuk berperan aktif dalam meningkatkan pengetahuan dan ketrampilan bidan.

Keberadaan puskesmas di setiap kecamatan yang hanya satu puskesmas masih dapat menjadi kendala untuk kecamatan yang secara geografis kondisinya tidak rata atau berada di dataran tinggi. Meskipun jarak tempat tinggal penduduk ke tempat pelayanan kesehatan sama, tetapi dengan kondisi jalan yang berbeda dapat menjadi kendala bagi masyarakat untuk datang ke puskesmas.

Jumlah tenaga kesehatan yaitu bidan di Kabupaten Brebes 
sebanyak 874 atau 49 per

100.000 penduduk, Dokter umum dan spesialis sebanyak 279 orang atau 16 per 100.000 penduduk. Adapun untuk dokter gigi dan spesialis gigi terdapat 23 dokter atau 1 per 100.000 penduduk. Jumlah bidan desa sudah ada di setiap desa sebanyak masing-masing satu orang. Adapun untuk jumlah dukun bayi di setiap desa ratarata lebih dari 5 orang, sehingga stau bidan harus mengampu 5 dukun bayi.

Upaya untuk menambah jumlah bidan desa di setiap desa tidak bisa dilakukan begitu saja oleh pemerintah daerah. Hal ini terkait dengan kebijakan pemerintah pusat yang menentukan jumlah bidan desa di setiap desa hanya satu orang. Kondisi tersebut terkait dengan kemampuan anggaran pemerintah.

d. Faktor masyarakat

Faktor masyarakat terkait dengan pengetahuan dukun dan budaya masyarakat. Dilihat dari faktor pengetahuan, pada saat sosialisasi tentang Peraturan Bupati Brebes No. 026 Tahun 2015, belum seluruh dukun bayi mengetahui dengan baik tentang isi peraturan tersebut. Informasi yang diberikan oleh dukun bayi sudah mendapatkan penyuluhan oleh bidan desa, tetapi mereka tidak banyak mengetahui isinya, meskipun sudah diberikan kesempatan untuk tanya jawab tetapi mereka tidak tahu apa yang harus ditanyakan.

Pegawai Dinas

Kesehatan dan Bidan desa sudah mencoba melakukan upaya yang diperlukan untuk meningkatkan ketrampilan dan pengetahuan dukun bayi agar mereka dapat membantu menolong persalinan yang lebih baik, sambil secara perlahan memberikan pemahaman tentang pentingnya persalinan ditolong oleh tenaga kesehatan dan dilakukan di fasilitas pelayanan kesehatan.

Program

Pembinaan Dukun Bayi dilakukan dengan menyampaikan materi pembinaan terkait dengan tiga periode penting meliputi kehamilan, persalinan dan nifas. Materi tersebut disampaikan secara bergantian oleh bidan puskesmas dan bidan desa yang bertindak sebagai pelaksana sekaligus pembina dukun bayi.

Kegiatan tersebut merupakan bagian dari kegiatan kemitraan bidan dengan dukun bayi yang merupakan salah satu program sebagai upaya untuk 


\begin{abstract}
meningkatkan cakupan pertolongan persalinan oleh tenaga kesehatan. Kemitraan bidan dan dukun bayi adalah suatu bentuk kerjasama bidan dan dukun bayi yang saling menguntungkan dengan prinsip keterbukaan, kesetaraan dan kepercayaan dalam upaya untuk menyelamatkan ibu dan bayi, dengan menempatkan bidan sebagai penolong persalinan dan mengalihfungsikan dukun dari penolong persalinan menjadi mitra dalam merawat ibu dan bayi pada masa nifas, dengan berdasarkan kesepakatan yang telah dibuat antara bidan dan dukun serta melibatkan seluruh unsur/elemen masyarakat yang ada.
\end{abstract}

Pemberdayaan

masyarakat dalam rangka meningkatkan kesadaran terhadap pentingnya kesehatan terus harus dilakukan. Proses perubahan perilaku dalam masyarakat untuk memiliki kesadaran tentang kesehatan tidak dapat dilakukan dengan cepat, mengingat perubahan budaya harus dilakukan dengan meningkatkan pengetahuan, merubah sikap dan membiasakan perilaku yang baru. Membangun kesadaran masyarakat merupakan awal dari kegiatan pengorganisasian masyarakat yang dilakukan dengan membahas bersama tentang harapan mereka, berdasarkan prioritas masalah kesehatan sesuai dengan sumber daya yang dimiliki.

Permenkes No. 65 Tahun 2013 Tentang Pedoman Pelaksanaan dan Pembinaan Pemberdayaan Masyarakat Bidang Kesehatan diatur tentang pemberdayaan masyarakat adalah segala upaya fasilitasi yang bersifat non instruktif, guna meningkatkan pengetahuan dan kemampuan masyarakat, agar mampu mengidentifikasi masalah yang dihadapi, potensi yang dimiliki, merencanakan dan melakukan pemecahannya dengan memanfaatkan potensi setempat.

Petugas kesehatan mempunyai peranan penting dalam pemberdayaan masyarakat. Adapun peran petugas kesehatan dalam pemberdayaan masyarakat adalah :

1. Memfasilitasi masyarakat melalui kegiatan-kegiatan maupun program-program pemberdayaan masyarakat meliputi pertemuan dan pengorganisasian masyarakat. 
2. Memberikan motivasi kepada masyarakat untuk bekerja sama dalam melaksanakan kegiatan pemberdayaan agar masyarakat

mau berkontribusi terhadap program tersebut

3. Mengalihkan pengetahuan, keterampilan, dan teknologi kepada masyarakat dengan melakukan pelatihanpelatihan yang bersifat vokasional. $^{21}$

Pembangunan kesehatan pada hakekatnya diarahkan guna tercapainya kesadaran, kemampuan dan kemauan hidup sehat bagi setiap orang, menyangkut fisik, mental, maupun sosial budaya dan ekonomi. Untuk mencapai derajat kesehatan yang optimal dilakukan berbagai upaya pelayanan kesehatan yang menyeluruh, terarah dan berkesinambungan. ${ }^{22}$

Pemberdayaan

masyarakat berperan penting dalam upaya mewujudkan kemandirian kesehatan. Pemberdayaan kesehatan di bidang kesehatan merupakan sasaran dalam promosi

${ }^{21}$ Syahrullegiarto. 2016. Op. cit.

${ }^{22}$ Diah Arimbi. Kajian Perbuatan Melawan Hukum Terhadap Wewenang Pelayanan Bidan Praktik Mandiri di Kabupaten Banyumas, Akademi Kebidanan Perwira Husada Purwokerto. 2012.hlm. 218 kesehatan. Pemberdayaan masyarakat merupakan salah satu dari strategi promosi kesehatan pemberdayaan sehingga pemberdayaan masyarakat sangat penting untuk dilakukan agar masyarakat sebagai memiliki kemauan dan kemampuan untuk memelihara dan meningkatkan kesehatan secara optimal.

e. Faktor Kebudayaan

Faktor budaya terkait
dengan kebiasaan turun
temurun di desa tentang
persalinan yang dibantu oleh
dukun bayi, sedangkan faktor
geografis terkait dengan jarak
rumah ibu bersalin dengan
tempat fasilitas pelayanan
kesehatan. Informasi tersebut
dibenarkan oleh dukun bayi
yang menyampaikan bahwa
sudah menjadi kebiasaan di
desanya, jika ada yang
bersalin akan meminta mereka
untuk menolong persalinan
termasuk merawat ibu dan
bayinya sampai 40 hari.

Menurut Soekanto, kebudayaan mencakup suatu sistem tujuan-tujuan dan nilainilai tertentu. Nilai sosial dan budaya berperan sebagai pedoman dan pendorong bagi perilaku manusia dalam proses 


\begin{abstract}
interaksi sosial ${ }^{23}$ Nilai-nilai sosial dan budaya yang berkembang di masyarakat terkait dengan pertolongan persalinan oleh dukun bayi tidak dapat begitu saja dirubah. Jika dalam suatu desa belum pernah terjadi permasalahan tentang kematian ibu dalam bersalin tentu sangat sulit untuk merubah kebiasaan mereka. Belum lagi jika masyarakat menganggap konsep kematian sebagai suatu yang tidak dapat dihindari. Kondisi tersebut dapat diperbandingkan dengan implementasi program keluarga berencana yang melalui proses sangat panjang, dan hingga saat ini masih saja terdapat sekelompok masyarakat yang menolak konsep keluarga berencana (KB).

Pelaksanaan maklumat dukun bayi yang diatur dalam Peraturan Bupati Brebes No. 026 Tahun 2015 yang masih terkendala faktor budaya masyarakat secara perlahan harus tetap diupayakan penyelesaiannya. Hal ini dapat dilakukan dengan melembagakan nilai-nilai yang baru yang dilakukan secara
\end{abstract}

23 Soerjono, Soekanto, Sosiologi Suatu Pengantar. Raja Grafindo persada. Jakarta. 2012. hlm. 24. terus menerus. Seluruh pihak yang berkepentingan harus memiliki komitmen yang kuat dalam mengimplementasikan peraturan yang sudah ditetapkan.

Kemampuan bidan yang makin meningkat akan meningkatkan kepercayaan masyarakat terhadap pelayanan kesehatan oleh tenaga kesehatan, sehingga secara perlahan masyarakat dapat berubah untuk memilih pelayanan kesehatan kepada tenaga kesehatan di fasilitas pelayanan kesehatan yang telah didirikan oleh pemerintah. Kemitraan bidan dan dukun bayi sebagai bagian dari kegiatan pemberdayaan masyarakat secara perlahan dapat merubah kebiasaan di masyarakat tentang pertolongan persalinan oleh tenaga kesehatan yang selama ini masih ada dilakukan oleh dukun bayi.

Implementasi peraturan perundang-undangan termasuk Peraturan Bupati Brebes No. 026 Tahun 2015 agar dapat dilaksanakan dengan baik diperlukan pemahaman yang baik oleh kelompok sasaran peraturan tersebut. Kegiatan sosialisasi menjadi faktor kunci dalam rangka mencapai hal tersebut. Berdasarkan pada 
677 | Jurnal Idea Hukum

Vol. 3 No. 2 Oktober 2017

Magister Hukum Fakultas Hukum Universitas Jenderal Soedirman

hasil penelitian diketahui
bahwa kegiatan sosialisasi
sudah dilaksanakan dengan
baik, namun demikian belum
seluruh kelompok sasaran
dapat memahami dengan baik
tujuan adanya peraturan
tersebut, hingga masih
terdapat dukun bayi yang
menolong persalinan di rumah.
Informasi yang diperoleh dari
bidan desa diketahui bahwa
pertolongan persalinan oleh
dukun bayi masih cukup banyak.
Namun demikian, tidak
teridentifikasi berapa jumlah
kematian ibu yang
persalinannya di tolong oleh
dukun bayi.

\section{D.SIMPULAN DAN SARAN}

\section{Simpulan}

Peraturan Bupati Brebes

No. 026 Tahun 2015 Tentang Pemberdayaan Masyarakat Dalam Penurunan Angka Kematian Ibu dan Angka Kematian Bayi Melalui Maklumat Dukun Bayi dilihat dari teori pencapaian tujuan, integrasi, adaptasi sudah efektif dalam menurunkan Angka Kematian Ibu di Kabupaten Brebes. Dilihat dari pencapaian tujuan, Jumlah Angka Kematian Ibu pada tahun 2014 sebanyak 73 orang, tahun 2015 menurun menjadi 52 orang dan tahun 2016 sebanyak 54 orang. Pada aspek integrasi, Peraturan Bupati Brebes No. 026 Tahun 2015 sudah disosialisasikan kepada kelompok sasaran yaitu dukun bati oleh petugas kesehatan baik di tingkat kabupaten, kecamatan dan desa. Adapun dilihat dari aspek adaptasi, Pemerintah Daerah dalam hal ini Dinas Kesehatan telah memiliki sejumlah fasilitas pelayanan yang dibutuhkan untuk pertolongan persalinan mulai dari keberadaan rumah sakit negeri dan swasta, Puskesmas di tingkat kecamatan dan Pos Kesehatan Desa (PKD di tingkat desa termasuk Balai Pengobatan/Klinik dan juga ketersediaan tenaga kesehatan yaitu dokter dan bidan yang memadai.

Hambatan pelaksanaan Peraturan Bupati Brebes No. 026 Tahun $2015 \quad$ Tentang Pemberdayaan Masyarakat Dalam Penurunan Angka Kematian Ibu dan Angka Kematian Bayi Melalui Maklumat Dukun Bayi yaitu faktor hukumnya karena belum adanya regulasi di tingkat desa. Dilihat dari penegak hukum akibat keterbatasan jumlah bidan desa di setiap desa yang tidak sebanding dengan jumlah dukun bayi yang rata-rata jumlahnya lebih dari lima di setiap desa. Faktor sarana atau fasilitas yang mendukung penegakan hukum terkait dengan letak geografis sehingga keberadaan puskesmas di setiap kecamatan masih menjadi kendala bagi masyarakat untuk mengakses fasilitas pelayanan kesehatan. Faktor masyarakat terkait dengan pengetahuan masyarakat dalam memahami pentingnya pertolongan 
persalinan oleh tenaga kesehatan di tempat pelayanan kesehatan. Faktor kebudayaan menyangkut perilaku masyarakat untuk melakukan persalinan di dukun bayi sebagai kebiasaan yang sudah turun temurun.

\section{Saran}

1. Dinas kesehatan hendaknya masih perlu terus mengawal pelaksanaan Peraturan Bupati Brebes No. 026 Tahun 2015 agar dapat dilaksanakan oleh seluruh aparat yang berkepentingan dalam rangka menurunkan Angka Kematian Ibu di Kabupaten Brebes.

2. Kemitraan bidan dengan dukun bayi hendaknya terus ditingkatkan untuk meningkatkan ketrampilan dan pengetahuan dukun bayi dalam menolong persalinan, dengan diikuti penyadaran tentang pentingnya persalinan dilakukan oleh tenaga kesehatan dan dilakukan di tempat fasilitas pelayanan kesehatan.

3. Pemerintah daerah hendaknya memfasilitasi terbentuknya peraturan desa yang dapat digunakan untuk pemberian sanksi terhadap pelanggaran Peraturan Bupati Brebes No. 026 Tahun 2015.

\section{DAFTAR PUSTAKA}

A Potter, \& Perry, A. G. Buku Ajar Fundamental Keperawatan: Konsep,. Proses, Dan Praktik, edisi 4, Volume.2. Jakarta: EGC. 2007.

Aeni, Nurul, "Faktor Risiko Kematian Ibu", Jurnal Kesehatan Masyarakat Nasional Vol. 7, No. 10, Mei 2013.

Arimbi, Diah. Kajian Perbuatan Melawan Hukum Terhadap Wewenang Pelayanan Bidan Praktik Mandiri di Kabupaten Banyumas, Akademi Kebidanan Perwira Husada Purwokerto. 2012.

Gutierrez. R, Gustavo, Vera.E, de Lean P, Vargas LF. 2007. "Risk Factors of Maternal Death in Mexico". Journal Birth, Volume 34, pp. 2125.

Hidayah, Wiwit dan Tri Anasari, "Hubungan Kepatuhan Ibu Hamil Mengkonsumsi Tablet Fe dengan Kejadian Anemia di Desa Pageraji Kecamatan Cilongok Kabupaten Banyumas". Jurnal IImiah Kebidanan, Vol. 3 No. 2 Edisi Desember 2012.

Kaddour C, Souissi R, et al. "Causes and Risk Factors of Maternal Mortality in the ICU", Critical Care, Volume 12 suppl 2. 2008.

Korten, David C. dan Syahrir. Pembangunan Berdimensi Kerakyatan, Yayasan Obor Indonesia. Jakarta. 1990.

Laksana, Nuring Septyasa, "BentukBentuk Partisipasi Masyarakat Desa dalam Program Desa Siaga di Desa Bandung Kecamatan Playen Kabupaten Gunung Kidul Provinsi Daerah Istimewa Yogyakarta", Jurnal Kebijakan dan Manajemen Publik, Volume 1, Nomor 1, Januari 2013.

Latifah, Emmy "Harmonisasi Kebijakan Pengentasan Kemiskinan di Indonesia Yang Berorientasi Pada Millennium Development Goals", Jurnal Dinamika Hukum, Vol. 11 No. 3.

Manuaba, C. Gawat-Darurat ObstetriGinekologi dan ObstetriGinekologi Sosial untuk Profesi Bidan. Penerbit Buku Kedokteran EGC. Jakarta. 2008. 
679 | Jurnal Idea Hukum

Vol. 3 No. 2 Oktober 2017

Magister Hukum Fakultas Hukum Universitas Jenderal Soedirman

Muninjaya. A.A. Gde Manajemen Kesehatan. Jakarta: Penerbit Buku Kedokteran EGC. 2004.

Ririanti, Mury, Determinan Proksi Dalam Gambaran Jumlah Kematian Ibu Berdasatkan Status Maternal di Kabupaten Jember Tahun 2007 2011, Prosiding Seminar Nasional Kependudukan, 2013. FKM Universitas Jember.

Soemitro, Ronny Hanitijo. Metodologi Penelitian Hukum. Ghalia Indonesia, Jakarta. 1990.

Soekanto Soerjono. Faktor - Faktor yang Mempengaruhi Penegakan Hukum. PT Raja Grafindo Persada, Jakarta. 1993.

Soekanto Soerjono, dan Sri Mamuji. Penelitian Hukum Normatif, Raja Grafindo Persada, Jakarta. 2003.

Sudrajat, Tedi dan Agus Mardiyanto, "Hak Atas Pelayanan dan Perlindungan Kesehatan Ibu dan Anak (Implementasi Kebijakan di Kabupaten Banyumas)", Jurnal Dinamika Hukum, Vol. 12 No. 2 Mei 2012, Purwokerto: Fakultas Hukum Universitas Jenderal Soedirman.

Syafiq, Ahmad, Angka Kematian Ibu dan Pendidikan Perempuan di Indonesia: Tinjauan Ekologis Provinsial, Makalah Konferensi Infid 2013 "Pembangunan Untuk Semua: Memperjuangkan Kualitas Pemerintah, Hak Asasi Manusia, dan Inklusi dalam Rencana Pembangunan Jangka Menengah 2015-2019", Hotel Royal Kuningan Jakarta, 26-27 November 2013 